Dao, T. L. (1969). The Human Adrenal Gland and its Relation to Breast Cancer, ed. K. Griffiths and E. H. D. Cameron, p. 99. Cardiff, Alpha Omega Alpha. Deshpande, N., Hayward, J. L., and Bulbrook, R. D. (1965). fournal of Ghosh, P. C., Lockwood, E., and Pennington, G. W. (1971). Steroidologia, Ghosh, P. C., Lockwood, E., and Pennington, G. W. (1972). Steroids
and Lipids Research, 3, 75.
Hsu, T. H., and Bledsoe, T. (1970). fournal of Clinical Endocrinology and Metabolism, 30, 443.

Kolanowski, J., and Pizarro, M. A. (1969). Annales d'Endocrinologie, 30, 177. Kumaoka, S., Sakauchi, N., Abe, O., Kusama, M., and Takatani, O. (1968). Fournal of Clinical Endocrinology and Metabolism, 28, 667.

Salih, H., Flax, H., and Hobbs, J. R. (1972). Lancet, 1, 1198.

Sneddon, A., Steet, J. M., and Strong, J. A. (1968). Lancet, 2, 892

Wade, A. P., Davis, J. C., Tweedie, M. C. K., Clarke, C. A., and Haggart, B. (1969). Lancet, 1, 853.

\title{
Pleural Effusion with Pancreaticopleural Fistula
}

\author{
M. TOMBROFF, A. LOICQ, J.-P. DE KOSTER, L. ENGLEHOLM, J.-P. GOVAERTS
}

British Medical fournal, 1973, 1, 330-331

\section{Summary}

Three patients with pleural effusion were found to have pancreaticopleural fistulas passing through an opening in the diaphragm are reported. In one case the effusion was purulent and originated from an abscess of the pancreas. Retrograde pancreatography during operation defined the course of.the fistula. In two other cases the fistula was demonstrated by radiography after intrapleural injection of contrast medium. The diagnostic importance of injecting contrast medium early into the pleural cavity in cases of effusion rich in amylase, before lung expansion obscures the fistula, is emphasized. Cases of pancreaticopleural fistula may be commoner than supposed.

\section{Introduction}

Pleural effusions associated with pancreatitis are generally thought to result from the diffusion of pancreatic enzymes into the pleura through transdiaphragmatic ducts. More rarely, cases have been reported of fistulization of a pancreatic pseudocyst either into the mediastinum along the diaphragmatic pillars (Stoppa, et al., 1970) or into the pleura via the diaphragm (Poppel, 1959; Roseman et al., 1960; Bergmann et al., 1965; Malaisse et al., 1967; Dubois et al., 1969). We report here three recent cases of pleural effusion of pancreatic origin in which there was a transdiaphragmatic fistula.

\section{Case Reports}

CASE 1

A 67-year-old man was admitted to hospital complaining of epigastric pain and loss of weight. There was no history of slcoholism, but 10 years previously he had been investigated because of epigastric pain and was found to have diabetes. Apart from epigastric tenderness, nothing abnormal was found on admission. A few days later a large left pleural effusion developed, accompanied by pyrexia. Paracentesis produced $600 \mathrm{ml}$ of purulent fluid from which mainly Gram-negative organisms were cultured. The amylase content of the pleural fluid was 280 Somogyi U/100 ml, whereas the serum amylase was only 140 Somogyi U/100 ml. Radiography showed a filling defect on the internal edge of the second part

Brugmann Hospital, University of Brussels, Brussels M. TOMBROFF, M.D., Associate, Department of Medicine A. LOICQ, M.D., Associate, Department of Medicine

J.-P. DE KOSTER, M.D., Head, Department of Chest Diseases L. ENGELHOLM, M.D., Associate, Department of Radiology J.-P. GOVAERTS, M.D., Associate, Department of Surgery of the duodenum due to external compression. This abnormality was confirmed by hypotonic duodenography.

These findings suggested a diagnosis of pancreatic abscess complicated by purulent pleurisy and this was confirmed by laparotomy, which revealed an enlarged, nodular, and hardened pancreas. Retrograde pancreatography during operation showed a dilated sinus communicating with a suprapancreatic convoluted abscess cavity which extended into the thorax by a narrow fistula. A pancreaticojejunostomy by the method of Roux was performed, and the postoperative period was uneventful. The effusion did not recur. Two years later the patient had a calcareous pancreatitis.

\section{CASE 2}

A 32-year-old man was admitted to hospital complaining of sudden onset of left-sided chest pain. He had a history of alcoholism and of attacks for several months of severe epigastric pain radiating to the back but not related to meals. After one of these attacks he underwent appendicectomy and resection of a Meckel's diverticulum, but without improvement in his symptoms.

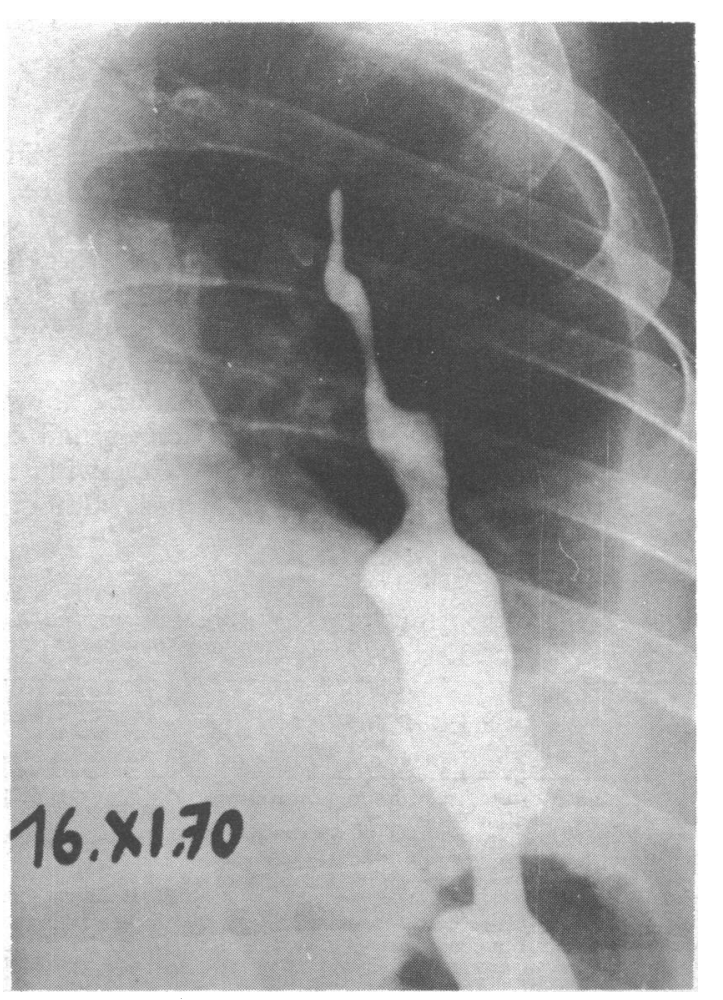

Anterior view. Patient is inclined almost $45^{\circ}$. The contrast medium is visible in the thoracic cavity, from which it extends through the diaphragm into the abdomen where it is superimposed on gastric shadow. 
Clinical and radiological examinations on admission showed a large, left-sided pleural effusion. The abdomen was not tender and no mass could be felt. The serum amylase was 816 Somogyi $\mathrm{U} / 100 \mathrm{ml}$, the urine amylase 237 Somogyi $\mathrm{U} / 100 \mathrm{ml}$, and the pleural fluid, which was haemorrhagic, contained amylase 33,500 Somogyi $U / 100 \mathrm{ml}$. Radiography showed a large filling defect in the second part of the duodenum. Lipiodol $6 \mathrm{ml}$ was injected into the pleural space and the progress of the contrast medium followed by fluoroscopy. When the examination table was inclined to about $45^{\circ}$ Lipiodol flowed freely through a posterior breach in the left diaphragmatic dome into the supramesocolic space (see fig.).

A drainage tube was inserted into the seventh intercostal space and $1,500 \mathrm{ml}$ of haemorrhagic fluid removed. A radiograph showed that the drainage tube had passed through the aperture in the diaphragm into the abdomen and was therefore draining both the pleural cavity and the supramesocolic space. The drainage tube was removed after three days. Recovery was uneventful and the patient has been symptomless for a year.

\section{CASE 3}

A 36-year-old man was admitted to hospital with haemoptysis, left pleural effusion, and pyrexia. He was a chronic alcoholic. He gave a history of bouts of epigastric pain for the past year, unrelated to food and radiating to the back. During this time he had lost $15 \mathrm{~kg}$ in weight. About $500 \mathrm{ml}$ of haemorrhagic pleural fluid containing amylase 17,700 Somogyi U/100 ml was withdrawn. The serum amylase was 580 Somogyi $U / 100 \mathrm{ml}$, and the urine amylase 4,200 Somogyi $U / 100 \mathrm{ml}$. Injection of $10 \mathrm{ml}$ of Lipiodol into the pleural cavity showed a large opening in the diaphragm communicating with a retrogastric cyst.

After repeated paracentcses the pleural effusion resolved and it had not recurred after six months. The amylase content of the pleural fluid gradually diminished and after 10 days it was 390 Somogyi U/100 ml.

\section{Discussion}

Pleural effusions associated with pancreatitis are usually haemorrhagic and have a high amylase content. The pleural fluid amylase was much higher than the serum amylase in $87.4 \%$ of the cases reported by Geffroy et al. (1968), and this was so in our three cases, notably in cases 2 and 3. Possibly in case 1 , in which the effusion was purulent, the amylase was partly destroyed by the pyogenic organisms.
Abscesses of the pancreas are rare. Two cases accompanied by non-purulent pleural effusion were reported by Kune (1968). A fistula is seldom present, and the injection of contrast medium into the pleural cavity has been rarely reported. Witz et al. (1967) reported two cases in which this technique was unsuccessful. Geffroy et al. (1968), however, diagnosed a case of pancreaticopleural fistula by this method. We believe the contrast medium must be injected early in the illness before re-expansion of the lung closes the opening in the diaphragm. If this were done we think more cases of pancreaticopleural fistula might be found. It is also essential progressively to move the patient during the radiological examination from the supine to the upright position. In our last two cases the contrast substance did not begin to flow until the table was sloping at $45^{\circ}$.

In pleural effusion of pancreatic origin the route by which amylase passes into the pleura is generally thought to be the transdiaphragmatic lymphatic ducts (Cunningham, 1922; Mitchell, 1964). Our three cases show that there is another way. Rapid drainage of the pleural effusion is essential and may also lead to the drainage of the pseudocyst.

We thank Professor P. P. Lambert, Head of the Department of Medicine, Blugmann Hospital, for helpful advice and criticism. We are grateful to Professor A. Verniory, Brugmann Hospital, and to Dr. Stanley J. Steel, of the London Chest Hospital, for critically reviewing the manuscript. The work benefited from a grant from Groupement Scientifique pour L'Etude et le Traitement des Affections Pulmonaires (G.S.P.).

\section{References}

Bergmann, F., Jacobs, E., Malaisse, W., and Thys, J. P. (1965). Acta Chirurgica Belgica, Suppl. III, 128.

Cunningham, R. S. (1922). American fournal of Physiology, 62, 248.

Dubois, J., Rousselle, L., and Piret, R. (1969). Acta Chirurgica Belgica, 68,

Geffroy, Y., Boureille, J., Morere, P., Sageot, M. C., and Colin, R. (1968). Semaine des Hôpitaux de Paris, 44, 1356

Kune, S. A. (1968). Australian and New Zealand Fournal of Surgery, 38, 125. Malaisse, W., Thys, J. P., and Jacobs, E. (1967). Acta Gastroenterologica Belgica, 30, 73 .

Mitchell, C. E. (1964). Annals of Internal Medicine, 60, 1047.

Poppel, M. H. (1959). Radiology, 72, 323.

Roseman, D. M., Kowlessar, O. D., and Sleisenger, M. H. (1960). New England fournal of Medicine, 263, 294.

Stoppa, R. et al. (1970). Annales de Chirurgie, 24, 1935.

Witz, J. P., Copin, G., Miech, G., and Weiss, A. C. (1967). Annales de Chirurgie, 21, 1313 .

\section{MEDICAL MEMORANDA}

\section{Skin Ulceration Caused by Salmonella dublin}

\section{W. CARSWELL, I. T. MAGRATH}

\section{British Medical fournal, 1973, 1, 331-332}

Localized infection is a not infrequent complication of salmonella bacteraemia, and occurs particularly where there is an underlying predisposition such as in bartonellosis and sickle-cell anaemia. Often there is pre-existing local disease such as haematoma, an area of infarction, a cyst, or a neoplasm. Local-

\section{Mulago Hospital, Kampala, Uganda}

W. CARSWELL, F.R.C.s., Senior Surgical Registrar

Lymphoma Treatment Centre, Kampala, Uganda

I. T. MAGRATH, M.B., M.R.C.P., Director ized infection outside the gastrointestinal tract commonly occurs in bone and joints, although parotitis, orchitis (Huckstep, 1962), splenic (Sharr, 1972), intraperitoneal (Griffiths, 1961), and breast abscesses (Barrett and MacDermot, 1972) have been described. Subcutaneous abscess from which Salmonella typhi was grown occurred in $2.9 \%$ of patients in one series of 240 adult cases of typhoid fever (Huckstep, 1962), but in none of these did ulceration occur. Skin ulceration resulting from cutaneous localization of salmonellae appears to be a rare event and should be clearly differentiated from decubitus ulceration and furunculosis associated with secondary pathogens, which may occur in severely ill patients.

We report a case of cutaneous ulceration occurring as the sole clinical manifestation of infection with Salm. dublin.

\section{Case History}

A 2-year-old girl of the Itesot tribe, from the Teso district of Uganda, was admitted to hospital on 8 May 1972. She had been in good health before the present illness. Two weeks previously 